\title{
Africa, Post-Global: A Reaffirmation
}

\author{
Tejumola Olaniyan
}

A response to my interlocutors and a reaffirmation, through a consideration of the place of Africa in the modern world, of the post-global as a productive reading frame.

Keywords: Africa, post-global, postcolonial, modernity, slavery, Afropolitanism, human rights, homosexuality, South Africa, Enlightenment

I have benefitted immensely from my interlocutors on these pages, so my abundant gratitude. Their interventions usefully demanded of me the addition of some foundational contextual matters, clarifications, and reiterations that are hopefully better formulated. I hope we are all the richer. Thanks to Postcolonial Literary Inquiry for organizing this critical forum.

What is most called for here is a post-global reading of modernity, and I have obliged with a fragment. On my desk is a secret self-chastisement I scrawled on a small card and kept facedown under a pile of books. I resort to it mostly when I am engaging matters of the African world in the modern era, that is, in the last five hundred yearsthat modernity is the large backcloth of our conversation on the post-global. The hidden scrawl, quite emphatic in its large cursives, is a scandal even to me: "We don't need more philosophy ("theory" writ large) but more historical sociology of philosophy." The statement itself, alas, is more philosophical than not, but I like to believe that it is serving its function well, which is really more of moderating and expanding than prohibiting. The statement, I think, is amply supported by a foundational evidence-in the grim statistics below-that is quite aphilosophical in nature if not in cause and impact.

$\begin{array}{lrr}\text { Century } & \text { Embarked } & \text { Disembarked } \\ \text { 1501-1600: } & 277,506 & 199,285 \\ \text { 1601-1700: } & 1,875,631 & 1,522,677 \\ \text { 1701-1800: } & 6,494,619 & 5,609,869 \\ \text { 1801-1866: } & 3,873,580 & 3,370,825 \\ \text { Total: } & 12,521,336 & 10,702,656^{1}\end{array}$

The figures tell one aspect, quantitative, of the story of the Euro-American transAtlantic trade in Africans as slaves. We all in African studies know or should know this.

Tejumola Olaniyan is Louise Durham Mead Professor of English and African and African Diaspora literary and cultural studies at the University of Wisconsin-Madison. (Email: tolaniyan@wisc.edu) 1 The trans-Atlantic slave trade, in figures. From the well-recognized database available at http://www. slavevoyages.org. The database is expansive and allows searches based on many parameters, accessed February 14, 2013. 
There is another aspect, qualitative, which we have found much harder to grasp. One reason for our difficulty is our unwillingness to learn more than about Africa, unwillingness to always seriously situate modern Africa in the modern world of which it is and has been an intimate part, right from the beginning. By default, we, its natives or vaunted defenders, contribute to silencing half of the modern African story. No one thinks twice about the centrality of Europe to world developments of the last five hundred years; the true surprise is that very few think of Africa that way in the same breath. Yet there is very little of modern European history that is not also a history of modern Africa, and the reverse is very true, logically. So, why should we be satisfied knowing one and not the other?

Let us take one very critical example. In European studies across the disciplines, the eighteenth century is a robust scholarly coverage area, but a deep amnesia structures the place of Africa in the studies. Most Africanist studies of that century remain equally narrow in its exclusivist focus on Africa and the imprint of Europe there in Africa. The eighteenth century in Europe was the "age of enlightenment" of the enthronement of reason against the ignorance and superstitious arbitrariness imagined for the Middle Ages. The era marked the emergence of the individual human person as an entity invested with unassailable dignity and freedom, freedom from the dictates of customs or religion, and "freedom to make public use of one's reason in all matters," as Immanuel Kant, one of the age's leading philosophers, puts it. ${ }^{2}$ The age gave the world its reigning modern ideas of freedom and human rights. Now, take a look at the statistical table again. Against the centuries between 1501 and 1866, you can see the corresponding numbers of enslaved Africans-both those shipped out of the continent and those who reached their various destinations. Well over half of all the enslaved Africans in the 366 years covered in the table were shipped out or disembarked in the eighteenth century. And what of before that precious century-the "age of enlightenment" did not, after all, just fall from the sky or emerge from the bowel of the earth fully grown? Is it possible for Europe to absorb that much foreign slave population, whether directly, or indirectly though the repatriation of the products of slave labor from dispersed locations, without being profoundly affected in so many ways by that population? Could there be any connection at all between those mournful statistics and the now globally cherished intellectual and philosophical developments of that century? Why is the "age of enlightenment" not part of the study of African history? There is just no reason at all other than our neglect. For the obvious reason of the physical presence of the African in generations, the American story is richer but only in some aspects. ${ }^{3}$ More generally, thanks to pioneer scholars such as Eric Williams (Capitalism and Slavery, 1944) and Walter Rodney (How Europe Underdeveloped Africa, 1972), it has since become less scandalous to write Africa into the primal origins of the industrial revolution and capitalism. Unfortunately, we have been far less bold in staking similar claims about and

2 Immanuel Kant, "What Is Enlightenment," Practical Philosophy, trans. Mary J. Gregor (Cambridge: Cambridge University Press, 1996 [(1784]), 18.

3 See the classic, Eugene D. Genovese, Roll Jordan Roll: The World the Slaves Made (New York: Vintage, 1976 [1974]). Even so, the bulk of the scholarship is more on the social lives and labor of the slaves than on their catalytic contributions to the dominant philosophies of rights and freedom. It is apparently just too hard to imagine the slave as the erased-out coauthor of the American Declaration of Independence, for instance. 
to modern rights and democracy, the origins of which are also in the same period and produced by the same forces.

Yes, the greatest ideas of rights and freedom emerged in the eighteenth century, but, from the slavery figures, we should not be scholarly surprised by that at all. The ideas of freedom that emerged then were totally new to humanity, but the kind of slavery that reached its peak at time-chattel slavery-had also never been seen before by humanity before 1400 and on that scale. A full 17 percent of the 12.5 million enslaved Africans had been enslaved by the first year of the eighteenth century. Before the first daybreak of that century, Africans had been subjected to chattel slavery for 199 years. Now, note that the reference database used for the table begins in 1501; but the standard accounting of the beginnings of African enslavement goes back to the 1440s with the first available account of shipping manifests. So, if we use 1451 - as did historian Philip D. Curtin, ${ }^{4}$ known for his conservative views on this matter-instead of the 1501, then we would have to say that before the eighteenth century, chattel enslavement of Africans had been in existence for 249 years.

It is clear to me then that a less reductively global, that is, a post-global, way to read the developments is that by the eighteenth century, European thinking public had, by accumulated knowledge over centuries, become only too acutely aware of the degradations of chattel slavery that they had to come up with ideas of freedom that would shield them from it. They benefitted from it but they also knew that they could not be shielded from it in the long run if they did not fight it. There was no thriving discourse of "enlightenment" or "modernity" in Europe that endured before chattel slavery began in the 1400s. Witness what happened to Magna Carta, or The Great Charter, of 1215, even so shallow and exclusivist as the liberties it proposed were. Modernity and modern freedom emerged precisely because of the chattel enslavement of Africans and the lessons learned from it. Why would more than 250 years of chattel slavery not, by the eighteenth century, begin to produce the most far-reaching ideas of freedom, particularly in the societies and especially the classes that reaped the most benefits in wealth, expansion and transformation of social relations, formal education, and leisure?

Chattel slavery was what set in motion the systematic thinking about person, personal dignity, and freedom that bloomed luxuriantly in the eighteenth century. Reason in the seventeenth century was supposed to provide ironclad justification for slavery, and it did successfully, for a while. Faced with enslaved Africans who lived, worked, suffered, conformed, rebelled, and died-in short, slaves who by their ordinary and extraordinary lives incontestably proved their humanity-reason by the last quarter of the eighteenth century could no longer find a reasonable reason for slavery. The difference of physiology that was adduced earlier to be unimpeachable evidence for deserved enslavement began to appear for what it had always been, a lie to vaseline venal economic interests. We could say that Immanuel Kant's Perpetual Peace (1795) marked the final moments of exhaustion of that justification. But mind you, Kant was concerned primarily about peace in his immediate region and those making it impossible: corrupt, warring, and tyrannical European rulers.

4 Philip D. Curtin, The Atlantic Slave Trade: A Census (Madison, WI: University of Wisconsin Press, 1969), 268. 
He condemned their vicious competition and depredations of diverse peoples abroad only because such depredation cannot in any way make for enduring peace and freedom at home. Surely, competition and commerce ought to be far less unruly, far more tamed, cleanly contractual, polite. Chattel slavery, the most intrinsically uncontractual and unruly trade ever, just no longer fits in the picture. Olaudah Equiano, one of our earliest writers, is probably the most eloquent on this, in the last few pages of his autobiography, The Interesting Narrative (1789). African chattel slavery served as the programmatic catalyst for "European" enlightenment thinking; Africa is the unacknowledged coauthor of that body of thought. That the current South African constitution is the most egalitarian in the world on rights-way beyond the mindset of a majority of South Africans and Africans generally, for instance, on sexuality ${ }^{5}$-is most fitting and should be much more philosophically and historically meaningful to us than it currently is. It is just not clear to me how our ancestors who paid for a radically new world with their blood will ever forgive us for our unselfconscious squandering of our heritage.

Were the resulting ideas of rights and freedom "culturally" European? It is surprising how common this idea is, and how very illogical. Worse, its greatest proponents are our most educated people. Why would the rights constitute so much revolution and be so contentious to put in place in Europe itself if they were already "cultural"? Why would an age so spectacularly stand out in "enlightenment" if the society was already at the highest limit of the existing, the imaginable, and the possible in social relations? If everything were going absolutely well, why would a society go through the great turmoil of restructuring and "enlightening" itself?

No, the rights were and are not culturally European; they became so, normalized, with great struggle. I know that in African discourse, very rightly, Europe has no credibility when it comes to claims of the universalism of some values. Chinua Achebe's early articulation of that criticism remains unforgettable, but it is also the case that we have boxed ourselves into a self-subverting corner by oversimplifying the critique. $^{6}$ There are at least two ways in which this is self-subverting us. The first and

5 In spite of the egalitarian character, a Pew Research Center poll in 2013 reported that only 32 percent of South Africans answered "yes" to the question, "Should Society Accept Homosexuality?" An emphatic 61 percent roared "no." Jacob Zuma, president, once sent a gay-bashing ambassador, Jon Qwelane, to gay-prosecuting Uganda. Qwelane, a convicted hate speech monger, even went to court to challenge the constitutionality of the Equality Act and wanted it struck down. Even more irony: that South African 31 percent "yes" was by miles the best in Africa, Kenya being next with just 8 percent. See Pew Research Center, "The Global Divide on Homosexuality: Greater Acceptance in More Secular and Affluent Countries," http:// www.pewglobal.org/2013/06/04/the-global-divide-on-homosexuality/, accessed September 1, 2013; Khaya Koko, "Qwelane Challenges Equality Act," Cape Times, December 14, 2016, http://www.iol.co.za/capetimes/ news/qwelane-challenges-equality-acts-validity-2096340, accessed April 22, 2017.

6 "In the nature of things the work of a Western writer is automatically informed by universality. It is only others who must strain to achieve it. So-and-so's work is universal; he has truly arrived! As though universality were some distant bend in the road which you may take if you travel out far enough in the direction of Europe or America, if you put adequate distance between yourself and your home. I should like to see the word 'universal' banned altogether from discussions of African literature until such a time as people cease to use it as a synonym for the narrow, self-serving parochialism of Europe, until their horizon extends to include all the world." Chinua Achebe, "Colonialist Criticism," Morning Yet on Creation Day: Essays (London: Heinemann, 1975), 9. As we can see in the last sentence, Achebe was not against universalism as such but a racialist and racist one. For a patient, close reading of the universality problematic in the context of the early debate over the language of African literature, see Moradewun 
more prosaic one is that as avid consumers of modern technology (include modern European languages as technology), we actually are not following and cannot follow our emotional preference for indigeneity over utility. We consume "Western" material things but do not want "Western" ideas and values like rights. Alas, things already come with values and interpersonal relations embedded in them, whether we know that or not. Mind you, that emotional misdirection of indigeneity over utility was created in us in the first place not by the essential reality of how the world works or should work, but by the contingent reality of racism, for its own sustenance. And we go on sustaining it.

The second is that those values and rights are indeed universal and not "Western." Africa was and is co-creator. That the articulators were Europeans is a generic issue-for, which society is not hierarchically organized such that the ruling ideas, good and bad, come from the most privileged members wherever they are geographically located? That Europe has benefitted more from those rights is also a generic issue-after all, which society is not hierarchically organized such that the top 1 percent benefits more than the remaining 99 percent from any invention of materials or values in that society? The world intensively became one society five hundred years ago, and the problem is that Africa has been at the bottom, a servant, in the sharing of the good though it contributed hugely in the building toil. Surely none of us should ever be caught at the party where they are discoursing that the servant does not contribute anything to the daintiness of the mansion and its operations? We have for long allowed mere freaks of nature-skin color, geographical separation, and the totally contingent spatio-temporally bound ways of life geography generates called "culture"-to becloud our judgment and blind us from recognizing our inheritance; we have allowed them to blind us into giving up our birthright for no pottage at all though we are starving. Why would we concede so cheaply what evidently cost so much African blood to produce? Even Walter Rodney inexplicably forgot this other, nonmaterial productivity of the labor of the enslaved Africans: their engendering the invention of a kind of freedom, based on the inviolability of individual human dignity, that would be infinitely self-renewing and self-generating into the future. ${ }^{7}$

The point Olakunle George raised about the "conceptual singularity of postcoloniality" (282) and the need to figure it closely in thinking the post-global is critical. More than all prior discourses of Afro-self-understanding in the modern era from antislavery and abolitionism through anticolonialism, civil rights and independence, it was postcolonialism, in its tutored agonistic multi-sidedness, that could be said to have, in the most far-reaching manner, relativized the Eurocentric archive by

Adejunmobi, Vernacular Palaver: Imaginations of the Local and Non-native Languages in West Africa (Clevedon: Multilingual Matters Limited, 2004), 79-88.

7 See also Tejumola Olaniyan, "Africa and the Eighteenth-Century: The Challenge of the Archive." Lecture, African Studies Program "Africa at Noon" Series, University of Wisconsin-Madison, September 4, 2013; and Tejumola Olaniyan, "Teaching Simon Gikandi's Slavery and the Culture of Taste," Research in African Literatures 45.4 (2014): 17-23. I have since learned even more on this line of thinking from Kwame Anthony Appiah's more expansively argued (diachronically and synchronically) BBC Reith Lectures, "Mistaken Identities," October-November, 2016. For a published excerpt, see Appiah, "There Is No Such Thing as Western Civilization," The Guardian, November 9, 2016, https://www.theguardian. com/world/2016/nov/09/western-civilisation-appiah-reith-lecture. Accessed May 6, 2017. 
shattering its power of truth. ${ }^{8}$ But the postcolonial also dared all oppositional discourses, including itself, to come up with an agenda that sees beyond inversion. Thus my reformed ideological criticism, in which George rightly sees "procedural selfreflexiveness," owes a lot to what he calls "postcoloniality as an epistemic event" (282). That event enables my skeletal post-global reading of modernity. The reading is my complementary answer, using different data, to George's answer to his question, "how might the temporality of modernity" in relation to Africa "allow us to offer our students a slant on the post-global age beyond familiar Western perspectives?” (283)

What Taiwo Adetunji Osinubi patiently lays in sharp relief is no doubt what he considers an itinerary in my writings toward such a slant. I have never gone back to map the route that way, but I am convinced, educated. The diaspora connection that Osinubi highlighted is particularly important (298). Even from way back in Nigeria, before the 1990s US moment that he noted as conjuncture, I had always found it difficult to think of Africa in the world without thinking its diaspora into the equation. And it has been a hard lesson since then searching for a productive way to do so, from keywords to analytical directions. Learning more about modernity and historicizing it considerably sharpened the picture. Because modern Africa has been so obviously marked by the world, the world seems to me to be its most proper frame, the type capable of giving the most meaningful agency to "on-site accents and epistemologies responding to local claims" (305) without forgetting the multidimensional genealogies of the constraints under which they work. Agency, after all, is at the junction of constraints and possibilities; the more we know the constraints, the more possibilities we would be able to wrestle out of them.

Yes, the thematic here has broader implications: as also postcolonial-general rather than exclusively Africa-specific, as Uzoma Esonwanne usefully reminds us, citing Arundhati Roy. It is the case, though, that systemic state failure, as one key evidence of the emptying out of the nation-state and territorial sovereignty, bore an unmistakable and most poignant African stamp in the twentieth century. That, of course, cannot be a reason to allow the proposed reformed "ideological test" to sneak corporeality in "through the back door" (267). I know examples have their politics, and I could and should have added names like Ruth First, Albie Sachs, Robert Mshengu Kavanagh, and more. ${ }^{9}$ To those who will outrightly label and dismiss Marxism as "Western," hopefully my portable reading of modernity can soothe some of the anxiety; the good thing is that I am convinced that they are objectively wrong. I am borrowing the same conviction to reiterate that my answer to the applicability of "posts" to the definitional question in African literature is still a firm "yes" rather than an equivocal "yes, but ..." No hegemonic discourse willingly imagines its own relativization or supersession, so globalization as we have it now is only being true to type in its incapacity to imagine its own "after." It is precisely for this reason that we need to confront it with that possibility and so puncture its dream of ineluctability.

8 Michel Foucault, "Truth and Power," Power/Knowledge: Selected Interview and Other Writings 19721977, ed. C. Gordon, (Brighton: Harvester Press, 1980), 109-33.

9 See Ruth First, Power in Africa (New York: Pantheon, 1970); Albie Sachs, "Preparing ourselves for Freedom," Spring Is Rebellious: Arguments About Cultural Freedom, eds. Ingrid de Kok and Karen Press (Cape Town: Buchu Books, 1990), 19-29; and Robert M. Kavanagh, Theatre and Cultural Struggle in South Africa (London: Zed Books, 1985). 
We are already imagining that here in our conversation; and the current global migration crisis, state turmoil, and religious terrorism in search of a different mode of community are also all aspects of the systemic indicators of the exhaustion of our hegemonic globalization and a yearning for something "after" it.

The appropriateness or otherwise of the term "post-global" is of particular concern to Laura Murphy, Kwaku Korang, and Pius Adesanmi. The reality is, any "post" in our field is actually easier to defend now than ever before. We remember the early venomous opposition to "post-colonial," followed in short order by endless discoveries of its utility and its untamable capacity to lacerate us with uneaseful selfconsciousness with each usage. I have calculated all careerist or opportunistic usages of "post-colonial" into this claim, and I still stand by its unquestionable applicability. ${ }^{10}$ There is virtually no field in the humanities and social sciences today in which postcolonial has not become a familiar productive analytical term. The lesson here is that we may be likewise onto something with "post-global." To perhaps go for a term like "not-yet-global" (290) as Murphy suggests would be odd because "global" was what triumphantly replaced the "three worlds" idea most decisively after 1989. In any case, Murphy herself already claimed that "[A]ll African writers since the fifteenth century were born into a world that is functionally global" (291), and I agree. Another term that is seeking traction out there is the "global south." It is surely a useful critique of the global, but it lacks the capacious vision of the post-global and instead simply seeks to reconstitute the old era of containerized "three worlds," now just into two, global south versus global north. The dividing line is too easy and too comforting in its starkness.

Murphy argues that there are many "tactics of dissent" coming out of Africa that show the inadequacies of the global, from Afropolitan expressions to "shadow economies" and "back channel networks that elude big man power" (292). This is true. However, the last two, shadow economies and back channels, cannot be seen or celebrated as "viable arenas of dissent against globalization and oga politics" (293) because that would be to clothe the beleaguered inadequate and abnormal in the garb of a sustainable alternative ecosystem. Perhaps we sell "dissent" too cheaply if we apply it this way? I strongly suspect the survivors would not want to be praised for surviving in those backchannel ways. Their "space-claiming" without our (scholars') typical "backward glance of space-clearing" (293) can only lead to voluntarism and self-subversion. We may actually lean more on the significance of space-clearing, after all, policies that affect millions on the street are never made on the streets but at ministries, in think-tanks and boardrooms, by highly educated people like us. I am suspicious of a similar opposition between and among writers, critics, and activists that would privilege one over the other or structure them in a hierarchy. We speak in different discursive registers and approach the same problematic from different but necessary angles. Neither writers nor critics nor activists have all the answers. I am hard pressed to see the energetic conversation we are having on these pages, rarified as it may seem, as inferior to digging a well in a remote Gambian village or running an

10 Pius Adesanmi helpfully referenced the Callaloo special issue I guest-edited in 1993 (volume 16 number 4) titled "On Post-Colonial Discourse." More than two decades later, I still have not found any point to remove from my critical defense of "post-colonial" in that issue. 
anti-corruption non-governmental organization in Lilongwe, or writing a fine Afropolitan novel. By all means there should be (and there are) people doing those, and some doing this, too, most committedly.

The answer, then, to Korang's exquisitely crafted query of "underrepresentation" versus "overrepresentation" (315) is that Africa for too long has suffered from the former in critical conceptual matters such as we are discussing here and that there is no risk of the latter at all. I have tried to demonstrate this in my reading of modernity. Modern Africa has always been globally central; it is in part our reticence and our grasping for "particularity" that silenced and continue to silence it. Korang's quote of Aime Cesaire's "caveat" about segregation and dilution is dated, in my understanding. The Cesaire statement belongs to an era when affirmation of racial-cultural difference was thought to be the most effective weapon against a racialist and racist imperialism. But even back then, the usefulness function of that affirmation was limited. The problem of Africa was never racial-cultural difference but the political-economic domination mapped onto it. The two are related but not the same. Africa has no metaphysical particularity or ontology that is hermetically sealed from that of other peoples,' or mystical in anyway. Racial or cultural difference is not the problem, and today, capitalism will enthusiastically enable and commodify your difference for you and profit handsomely from it. Africa's particularity is utterly secular, historical, and eminently nameable: globalized exploitation in which race was a long-settled tool. This is Africa's difference that resists commodification-because the inequality that defines it continues to be unappeasably and unappetizingly glaring-and it is the one difference that matters. The composite African struggle then is to decouple race and exploitation and end exploitation as such, whatever the identity it latches on to. Korang asks: "[W]hy choose to make Africanist knowledge answerable to global time and not local time? If Africa must keep a certain time in comprehension, why must this time be computed expansively, in world-historical terms, and not modestly, in Afro-historical terms?" (309). The answer is because Africa has already long been world-historical in its reality if not yet in our conception; its local time already global time. Korang suggests "Post-Rwanda time," for instance. But Rwanda as we know it was created by some European men in Europe just a few decades ago, and what happened in Rwanda in 1994 cannot be fully understood without our returning to that primal scene. "Post-Rwanda time" is already muscularly world-historical and only partly African.

The foregoing also answers Adesanmi's concern that "globality and post-globality are preys of opportunity" (278) that settle on Africa after its early "internal" coherence and unity fashioned by the anticolonial nationalists were later "relinquished . . . in favor of other modes of identity interpellation" (278). Given what we know of the kind of state structures and geopolities the nationalists inherited from the colonial state, and given what we know about how very quickly after independence things began to fall apart, Adesanmi may have overstated the "mobilizing power" (277) of the nationalists. In any case, there was little that was "internal" (278) then that was not also external, after all, the nationalists were running a borrowed imported governmental system, bureaucracy, judicial system, and even the language of government-which only a minority of their citizens could speak. There was nothing "transcendental" (278), philosophically speaking, about the nationalists' accomplishment, except we are being 
ahistorical about their heroic labor of struggling to manage an inescapable wobbliness right from day one of independence. I am not distressed with cosmopolitanism, Afropolitanism, or Afropeanism as such. They are some of the legitimate even if debatable ways of being African in our contemporary moment. Myself as Africanborn but for long a professor of English and African studies at an American university, I would be lacking in self-consciousness to imagine that one or more of those labels do not or cannot describe me. The supposed disavowal of Africa that is supposedly common among some writers and scholars is an old theme that never fails to stoke the Afro-defensive nativism in especially those of us well-heeled enough in the world to be prone to such disavowal in a moment of less care; hence we are overly sensitive to its flimsiest glimpse everywhere. This is needless self-enervation on all sides. It is also a self-subverting distraction from our urgent charge today. What Adesanmi calls "the compulsion to disavow" (274) is as much a smugly pathetic mission as the compulsion to avow or the compulsion to police who is on which side. I am persuaded more by Murphy's measured reading of Afropolitanism here.

I think Adesanmi laments the rise of "post-truth" because he reads that phrase too literally. Truth is always intricately connected to power, and the connector is politics. If a regime of truth is dominant and settled for any stretch of time, it only means that the connector, politics, has been working well. "Post-truth" describes a condition of dysfunction with the connector, politics. Such a moment is not intrinsically good or bad, as it is a precondition for social change and renewal, for the reconstitution of society. The problem arises when backward-looking and anti-egalitarian forces are able to seize a moment of dysfunction in politics, as we have now in Trumpian America and other places. They are not "post-truth" but just installing their own truth and the politics that fit it. All of which goes to prove my point: that the current global moment is wobblier than ever and no longer sustainable. The rise of rear-guard actions and movements and stalled spring uprisings only consolidate the point, not debunk it. We who do not agree with those backward-looking movements need to seize the moment to reconstitute a better arrangement; the post-global as vision and conceptual handle is one encouragement in the task.

All my interlocutors agree on one urgent professional task for us: the search for increasingly more imaginative resources-theoretical and pedagogical models, rethinking roles for scholarly associations of literary study, literary and extra-literary activist work the ultimate goal of which is a richer infrastructure for our work, and more-to more effectively speak the reality of modern Africa. Luckily, a fruit is hanging low enough and we can start small there: begin to mainstream a minority strand in our critical tradition by pushing a revamped ideological literary criticism into more expansive cultural criticism. 